UNRESTING CELLS

by R. W. Gerard

Harper \& Bros., N.Y., 439 pp. \$4.

Reviewed by Arthur W. Galston

Senior Research Fellow in Biology

This is a well conceived and highly readable book dealing with the basic characteristics of living systems. It is pitched at the level of the intelligent layman, and its highly literate author succeeds remarkably well in preserving both scientific accuracy and reader inter. est. As scientists and laymen alike can testify, this is no mean task.

It should be noted that this is not, strictly. speaking, a new book. It was completed at the outbreak of World War II, and because of paper shortages and the diversion of biological personnel to more applied fields, soon passed out of print. The fact that it is now being reissued in its original form does not mean that it is outdated, for as the author reminds us, the normal pursuits of science were so interrupted by the war and its aftermath that very little fundamental work was produced which could alter any of our basic biological concepts.

The author's purpose in writing such a book is best expressed in his own words: "I have become ever more convinced by the sweep of world events that the scientist-yes, the pure scientist - is not merely justified in expending some energy on the popularization of sound science, but even more, has some duty to civilization to do so :. . Scientists must help recruit men in other walks of life to the use of the method and attitude of science in dealing with problems of state and society."

The opening chapters deal with the fundamental attributes of protoplasm and its possible mode of origin here or on some distant planet. Then, after a brief excursion into basic chemistry, the author returns to biology to build his complicated organism out of the well-defined concepts he has presented. Chapters on Enzymes, Metabolism, and Energy describe the manner in which organisms utilize the molecules about them for the work which they must do if they are to preserve their biological integrity. The sub. sequent chapters deal with such topics as cell structure, growth, differentiation, reproduction, and heredity.

The greatest single virtue of the book is that it reflects the author's carefully considered scale of values. Concepts are properly regarded as the book's major domain; specific facts and details are introduced only in such quantity as is necessary for the proper development of the concepts. The gratifying result is the reader's feeling that an organism does possess, above all, unity. In an era when most biologists stress isolated enzymes, analytical procedures, and the progressive dismemberment of the organism, it is encouraging to see so capable a synthesis at the elementary level.

In general, this is highly recommended reading for all non-biologists. Engineers and physical scientists especially will quickly learn to talk the biologist's language by a careful perusal of this work.

\section{RESEARCH IN INDUSTRY}

Edited by $C$. C. Furnas

D. Van Nostrand, N.Y., 574 pp, $\$ 6.50$

Reviewed by Frederick $C$. Lindvall Professor of Electrical

and Mechanical Engineering

Industrial research in the United States has become a billion dollar business. This present level of annual activity has been achieved in a relatively few years, stimulated in large measure by the preparations for and prosecution of World War II. In 1920 approximately 7,000 people were employed in industrial research in 300 laboratories. The growth was slow in the early twenties, but has continued at an accelerating rate, attaining in 1940 an employment level of approximately 70,000 , and in 1948 somewhat over 150,000 in 2,400 laboratories.

During this period of rapid expansion many of the growing. pains common to the various laboratories in this new segment of American industry were studied by the National Research Council through its Division of Engineering and Industrial Research under such Council leaders in research as Dr, Frank B. Jewett and Dr. R. A. Millikan. In addition,
The

Nesen method of

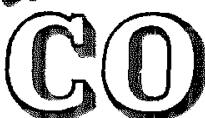

DITTCTION

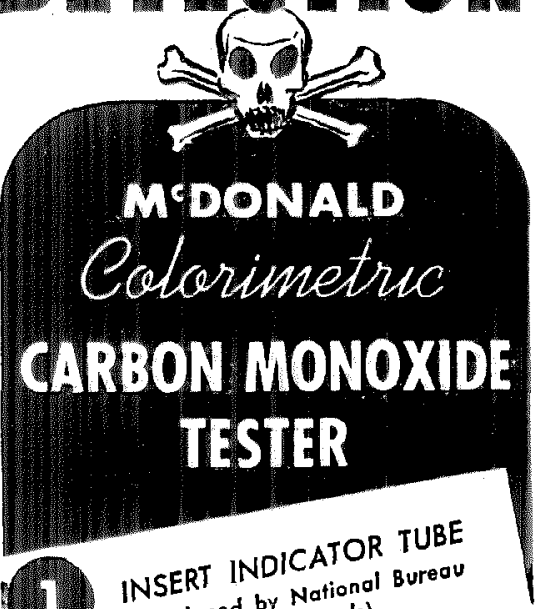
(developed by Nationds)

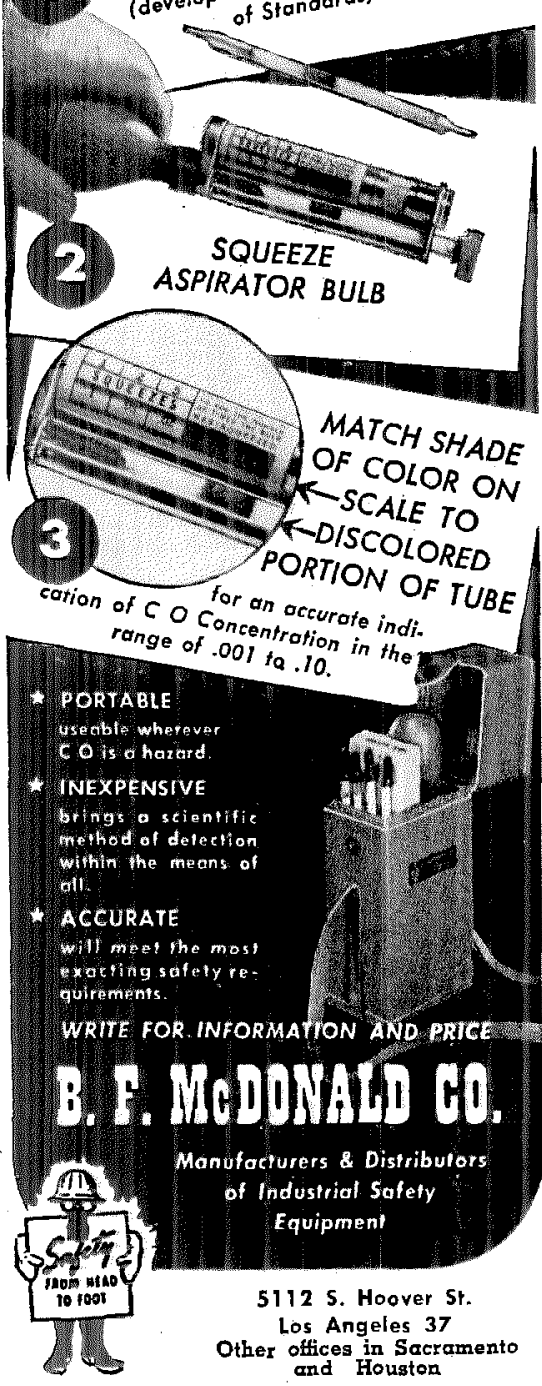


to achieve even greater effectiveness in the study of the problems of industrial research management, the National Research Council fostered the founding of an independent organization known as the Industrial Research Institute. This Institute is limited in total membership, in order that its conferences may not become unwieldy, but fairly represents the industrial research laboratories of the country in size, scope, and objective.

The Industrial Research Institute, established in 1938, had as its general aims:

(1) To promote, through the cooperative efforts of its members, improved, more economical and more effective techniques of organization, administration, and operation of industrial research.

(2) To develop and disseminate information as to the organization, administration and operation of industrial research.

(3) To stimulate and develop an understanding of research as a force in the economic, industrial, and social activity of the nation.

(4) To promote high standards in the field of industrial research.
From the subsequent conferences of the Institute much general infor. mation of value to research admin. istrators has accrued. A compilation of some of these results is now generally available in Research In Industry, edited by C. C. Furnas, Director of the Cornell Aeronautical Laboratory.

The twenty-nine chapters of the book are contributions of represen. tatives of various member companies of the Industrial Research Institute. They range all the way. from "The Philosophy and Objectives of Research in Industry," "The Research Director's Job," "The Research Budget," "Salary Policy," "Professional Growth of the Research Man," to "Relations with the Public and Govcrnment," "Research in America and Europe," and "Goals and Problems for the Future."

Three of these chapters are by Caltech alumni. W. R. Hainsworth, who wrote the chapter "By-Products of Research," and, jointly with R. S. Taylor, that on "Translating $\mathrm{Re}$ search Results into New Products and Factory Procedures," received his M.S. from Caltech in 1918, the second M.S. to be granted by the Institute. Hainsworth is Vice-President of Servel, Inc. Paul D. V. Manning, author of the chapter on "Goals and Problems for the Future," received his M.S. here in 1917, the first to be granted by Caltech. Manning is Vice-President in Charge of Research of the International Minerals \& Chemical Corporation.

The volume is in no sense intend. ed to be a handbook or manual of research administration, but nevertheless it includes many valuable examples of tested practices and pro. cedures in industrial research management. This information, together with the discussion of the more general topics of research philosophy and objectives, the functions of the research director, the research program itself, and the position of the research laboratory in the corporate structure, will be of much value to research administrators in reviewing their own objectives, study of reorganization and expansion problems, and in planning organized procedures in research activities in which growth now demands more formal organization. Corporate management also will find much of value in the book in clarifying the position and function of industrial research in re. CONIINUED ON PAGE 32

\section{adequate wiring... 11) a small part of the cost a large part of the value!}

In the cost of a home-and only there-Adequate Wiring is a minor consideration. The facilities

for better living-plenty of circuits, outlets and switches-can be included at a very small percentage of the total building cost. The figures on a home's value tell quite a different story.

Here the worth of Adequate Wiring far outweighs the investment. It means more comfort and conventence, steps saved, dangers avoided, efficient operation of appliances and economical

installation of new ones. These benefits in livability keep a home modern, so value stays up.

If you are building or remodeling, an Edison Adequate Wiring advisor will help with your plans.

His services are available to owners and contractors in Edison territory, without cost or obligation. 


\section{Books}

CONTINUED FROM P. 4

lation to the rest of the business.

One chapter, "Relations with the Educational System," should be of particular interest to colleges and universities, because it discusses from the point of view of an industrial research director many of the same problems which plague college administrators in dealing with questions of applied research, fundamental research, and patents in relation to industrial sponsorship. This chapter raises more questions than if answers, but serves a valuable function in making the implication that much more study should be given to the common problems of academic and industrial research. The present growth of academic research into areas of applied research and development has already created serious problems of policy in academic administrations.

\section{THE CRITICAL READER}

Edited by Wallace Douglas, Roy Lamson and Hallett Smith W.W. Norton \& Co., N.Y.,785 pp, \$5.

The poems, stories, and essays in this anthology have all been chosen for their ability to develop critical judgment in a reader. Beyond that, they have little in common - which means there are a good many offthe-beaten-track selections mixed in with standard anthology fare here. The book is primarily intended as a college textbook in freshman Eng. lish. As such, it is readable, stimulating, and difficult. In fact, it should present a considerable challenge, not only to the critical judgment of a freshman today, but to the oldtimer who, as a freshman, was weaned on such simple stuff as Wordsworth, Lamb, and Hawthorne.

Co-editor Hallett Smith is the new head of the Humanities Division.

\section{NATURAL HISTORY}

\section{OF MARINE ANIMALS}

by G. E. MacGinitie

and Nettie MacGinitie

McGraw-Hill, N.Y., 473 pp, $\$ 6$.

As Director of the Kerckhoff Marine Laboratory at Corona del Mar, George MacGinitie has been answering questions about the natural history of marine animals for a good many years. Now, with the assistance of his wife, he has collected some of this information in a book, written for the general reader as well as the zoology student, and dedicated "to those people who, after watching the activities of some of our marine animals, have said, "You ought to write all this down'."

\section{(D)TSTENDINGG}
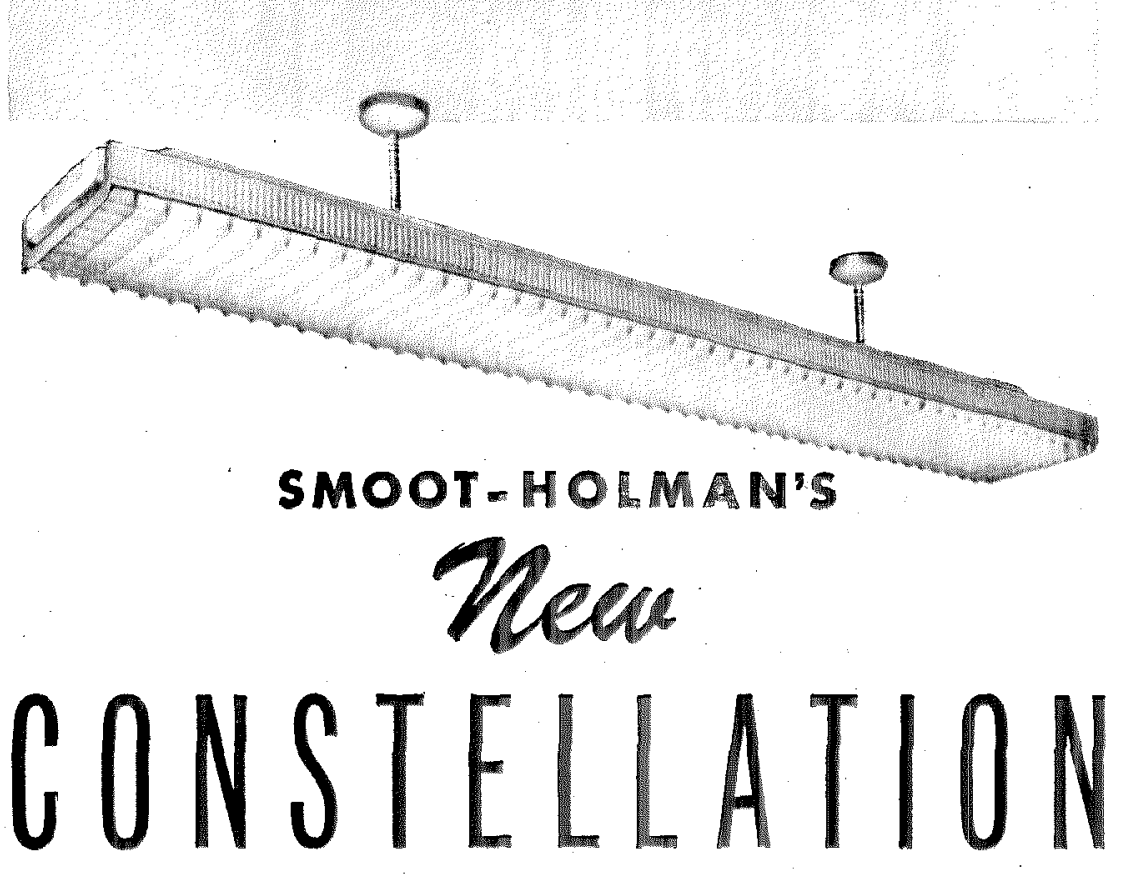

\section{SLIMLINE FLUORESCENT}

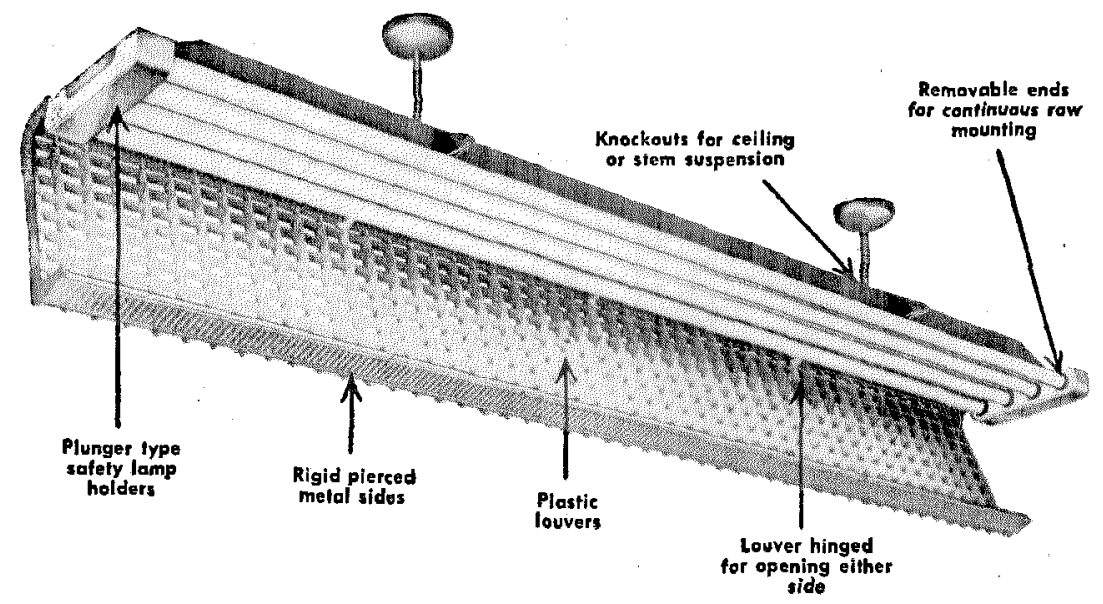

This outstanding luminaire utilizes the brand new high output 75 watt, 430 m.a. T-12-96" fluorescent lamp. It is scientifically engineered to produce the utmost in lighting quality and efficiency. "Wonderful - l've never seen such a beautiful unit!" says a leading illuminating engineer.

\section{WRITE FOR CIRCULAR}

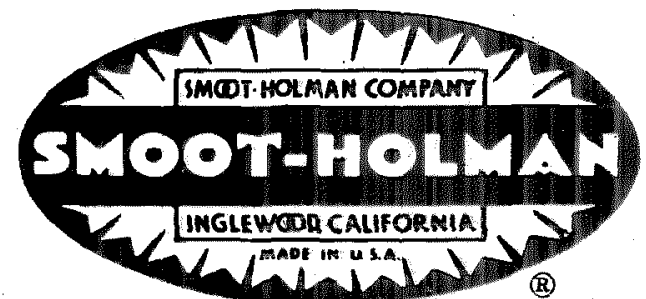

offices in Principal Western Cities - Branch and Watehouse in san Francisto 